\title{
Gambiarra as an Emergent Approach in the Entanglement of the Organizational Aesthetic and Technical Controversies: The Samba School Parade Case
}

\author{
César Tureta ${ }^{1}$ \\ Bruno Luiz Américo² \\ ${ }^{1}$ Universidade Federal do Espírito Santo, Vitória, ES, Brazil \\ ${ }^{2}$ Instituto Federal de Santa Catarina, São José, SC, Brazil
}

Received 26 October 2019. This paper was with the authors for two revisions. Accepted 22 November 2020.

First published online 17 December 2020.

Editor-in-chief: Carlo Gabriel Porto Bellini(D) (Universidade Federal da Paraíba, João Pessoa, PB, Brazil)

Associate editor: Pedro Jácome de Moura Jr(D) (Universidade Federal da Paraíba, João Pessoa, PA, Brazil)

Reviewers: Dan Eugen Ratiu(D) (Babes-Bolyai University, Romania) and two anonymous reviewers

Editorial assistants: Kler Godoy and Simone Rafael (ANPAD, Maringá, PR, Brazil) 


\section{ABSTRACT}

This paper aims to analyze the aesthetic and material/technical controversies surrounding the production of parade floats from a samba school. Starting from actor-network theory and controversy analysis, we show how actors negotiate interests that exist in carnival production project. Our findings demonstrate that the disagreements over material and aesthetic dimensions are temporarily solved by gambiarra, which is the unconventional use of technical knowledge for generating a creative solution in resource and time constraints contexts. We also argue that controversy analysis is an interesting tool to study organizational aesthetics in project management: it allows for understanding the potential conflictual relationship between material/technical and aesthetic dimensions. We conclude by stating that gambiarra can have both positive and negative consequences of generating creative solutions for controversies.

Keywords: organizational aesthetics; actor-network theory; controversies; gambiarra; creativity.

JEL code: MO. 


\section{INTRODUCTION}

The aesthetic dimension of organizations got researchers' attention in the 1990s (Gagliardi, 1990; Strati, 1996) and has since gained prominence as a way to understand organizational life (Stigliani \& Ravasi, 2018; Strati, 2016; Weggeman, Lammers, \& Akkerman, 2007). It draws attention from organizational studies to the sensuous experience/practice of art and how to research it (cf. Strati, 2009), focusing on actors' practical knowledge that emerges as they use their tastes and senses (Strati, 2008b).

Organizing aesthetics is not a smooth process and may be full of conflicts. Recently some researchers have identified an intricate relation between the material/technical and aesthetic dimensions, which may be based on tensions and disagreements regarding the way they are performed by actors (e.g., Austin, Hjorth, \& Hessel, 2018; Puyou \& Quattrone, 2018). In this sense, one of the promising fields of organizational aesthetics is the analysis of the role of artefacts in aesthetic production (see Puyou \& Quattrone, 2018; Strati, 1996). However, although the aesthetic approach considers the materiality of organizational daily life (Gagliardi, 1990; Strati, 2007; Strati, 2010a), empirical studies tend to marginalize technical artefacts (Siciliano, 2016) considering its relations with the human in a separate way rather than symmetrically (Law, 1994). So, the entanglement of social and material elements (Scott \& Orlikowski, 2014) and its potential conflicts have been underexplored in this field of study.

To overcome this limitation, we will use controversy analysis. Controversies are the disagreements between actors who question what was taken for granted (Venturini, 2010a). As highlighted by Venturini (2010a), controversy analysis can be used as a starting point to investigate the hidden aspects of a particular phenomenon, such as those that are rooted in sensible knowledge and agonistic/symbiotic relationship with cognitive knowledge (Strati, 2009, p. 243), once they show the social in its lively form. In this sense, linking up with actor-network theory (Latour, 2005; Law, 1992) and controversy analysis (Venturini, 2010a, 2010b; Hussenot, 2014), we aim to analyze the aesthetic and material/technical controversies surrounding the production of parade floats from a samba school.

The floats are huge 'cars' used to present an allegory throughout the parade. They are the most visible aesthetic dimension presented on the parade day. We study the floats' production from a samba school in the city of São Paulo. In recent years, the demand for high visual performance at the carnival (Duarte, 2013) and the competition between samba schools have grown rapidly, bringing greater attention to the aesthetic dimension details during the parade day (Rosa, 2013). Therefore, samba schools are constrained to enchant viewers and jurors, expending a large number of resources that are not always available at the time of producing the floats. To achieve high performance in the carnival project under time and resource constraints, creativity and inventive solutions are needed both to solve the problems and controversies that arise throughout the production of floats and to develop a charming parade.

The samba school parade is an annual project that involves typical elements of project management such as time, cost, scope, and quality objectives (Müller, Drouin, \& Sankaran,
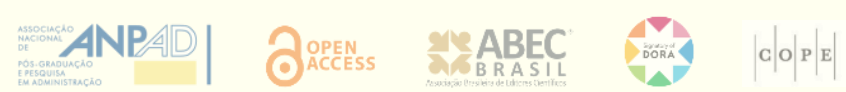
2019). Specifically, our investigation focuses on the aesthetic dimension of project life "ordinary beauty but also ordinary ugliness; the sublime as well as the disgusting; the elegant as well as the grotesque" (Strati, 2010a, p. 80). Once these aspects related to the aesthetic dimension are evident in samba schools' context, we can obtain relevant insights into the phenomenon under analysis (Siggelkow, 2007). We identified the employment of gambiarra as an unconventional use of technical knowledge to solve emergent organizing problems. This element links the technical and aesthetic dimensions of the carnival production and helps samba school members deal with disagreements between them.

The paper presents two contributions. First, we contribute to the literature of organizational aesthetics by developing the concept of gambiarra as a way to solve controversies between the aesthetic and technical dimensions. Gambiarra involves the use of sensible knowledge (Gherardi, Nicolini, \& Strati, 2007; Strati, 2016) arising from actors' practice to produce an original and creative solution (Amabile \& Pratt, 2016) in situations where there are time and resource constraints, as well as different interests at stake. More specifically, we add the notion of gambiarra to a new stream of project management research that seeks to discuss the role of aesthetics in this field by extending the scope of the investigation beyond the rational and analytical focus (Hoorn $\&$ Whitty, 2016). Second, we show that controversies analysis is an interesting tool for studying organizational aesthetics, as through them researchers can easily identify a starting point to map the network (Venturini, 2010a) and an association (Latour, 2005) of heterogeneous actors involved in the phenomena under analysis. Aesthetics is not a smooth issue in organizations, but one that is subject to multiple controversies.

\section{THEORETICAL BACKGROUND}

\section{Organizational aesthetics}

The organizational aesthetics approach emerged in the 1990s (Strati, 2008a). This approach is an alternative way of understanding organizational life through the feelings, desires, and tastes of individuals (Gagliardi, 2006; Strati, 2010a). Aesthetics deals with the knowledge produced by sensory experiences (Taylor \& Hansen, 2005) that vary among individuals as they make judgments using their own senses (Strati, 2008b; Stigliani \& Ravasi, 2018). Aesthetics can be understood as a form of organizational knowledge (Stephens \& Boland, 2015; Strati, 1996); of knowing by acting, since "it requires the active (conscious or otherwise) participation of whoever is involved in managing as designing" (Strati, 2005a, p. 920). It is related to criteria used to judge (Taylor \& Hansen, 2005) what is ugly or beautiful according to individuals' tastes (Strati, 2010a).

The research subjects of organizational aesthetics bring forward partial/particular representations of organizational phenomena, making "it legitimate to have conversations about how it feels to be in an organization" (Taylor, 2002, p. 838. In these terms, aesthetic experiences differ in organizations leading to a constant dynamic of judgment and negotiation around what is beautiful/grotesque, that is, "organizational aesthetics resists deterministic definitions" (Strati, 2010a, p. 82). This is the case of this particular samba school, whose knowledge-creation process cannot be described only by the dominant logic-analytic paradigms. The sensible knowledge

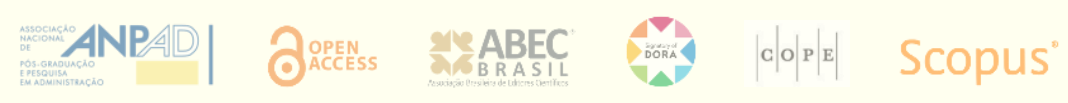


emerges from individuals' aesthetic judgment (Gherardi, et al., 2007; Strati, 2016) concerning material elements of their organizing activities (Puyou \& Quattrone, 2018). This sheds light on the organizational artefacts (Strati, 2007).

As stated by Strati (2007), "the 'materiality' of everyday life highlights quotidian social practices in organizational contexts (Strati, 2007, p. 65)" and its aesthetics can bring organizational knowledge into being (Strati, 1996). New ideas can be defined and understood through artefacts (Boxenbaum, Jones, Meyer, \& Svejenova, 2018), which are products that can only become perceptible through human senses (Gagliardi, 1990). Thoughts and speeches disappear easily; on the other hand, material lasts (Gagliardi, 2006) and travels from a place to another carrying and transforming meanings and relationships (Latour, 2005). Therefore, organizational knowledge is not only mental but also material (Gherardi, et al., 2007; Strati, 2008a). It is embedded "in the relationships between it and the organizational artefacts in use” (Strati, 2010a, p. 881).

For example, Strati (1996) analyzed how the chair provides different connotations for an organization since it can indicate the level of the position in the organizational hierarchy or the type of activity that is being conducted in a given space. Puyou and Quattrone (2018) studied aesthetic codes in the history of accounting from textual, visual, and material artefacts. The authors show that these elements help practitioners establish and maintain ties between them and to acquire legitimacy in society. Stigliani and Ravasi (2018) discuss how design professionals express and share their aesthetic experiences from intuitive judgment to more deliberate elaboration of ideas embodied in artefacts, indicating experience and judgment as two distinctive elements of organizational aesthetics (Strati, 2009).

Artefacts are a bricolage and a combination of different models of various materials, remaining malleable even after its design has been finished (Weick, 2003). In this sense, they are a pathway of actions (Gagliardi, 1990): they have the power to lead and "structure sensory experience and enlarge or narrow the range of behavior that is materially possible” (Gagliardi, 2006, p. 708).

Action is the result of the association between humans and non-humans (Callon, 1986; Latour, 2005). Assuming these assumptions, we can benefit from actor-network theory and controversy analysis to bring heterogeneous relationships to the forefront of organizational aesthetics.

\section{Actor-network theory and organizational aesthetics}

Actor-network theory (ANT) allows us to analyze cases in which the separation between humans and non-humans is unclear and actors have various forms (Callon, 1999). The fundamental question for actor-network studies is not how the social is formed, but how things and people connect (Latour, 2005; Czarniawska, 2006). For ANT, organizations are the assemblage of a set of technical and social elements, which should be analyzed in the same terms (Hassard, Law, \& Lee, 1999). This implies that putting human experience and sensitive knowledge apart from materiality can limit tracing and understanding the various actors involved in organizing aesthetics. 
Despite the potential of ANT for the analyses of organizational aesthetics, few studies have proposed this dialogue. So, ANT was little explored as a possible approach to account for the aesthetic nature of the organizational phenomenon. Some authors have raised caveats about embrace ANT for studying organizational aesthetics, especially regarding the concept of nonhuman agency (e.g., Ratiu, 2017; Strati, 2010b). Ratiu (2017) recognizes the participation of artefacts in the production of organizational aesthetics but, unlike ANT, follows Strati (2010a, 2010b) in placing a different emphasis on the pathos and corporeality of human actors while distinguishing between these and non-humans.

Although Chugh and Hancock (2009) present a similar interpretation of Strati, in stating that non-humans do not generate "their own ontological specificity in some purposive fashion, (Chugh \& Hancock, 2009, p. 463)" the authors argue that actants do not have an agency outside the network in which they are inserted. Accordingly, the authors showed that the aesthetic qualities of hairdressing salons were produced by the interactions of various actors in a specific network. Human and non-human "only come into being as actants within that network," that is, they are embodied with agency when associating with each other. This is precisely what Latour (2005) advocate: "We have to accept that the continuity of any course of action will rarely consist of human-to-human connections ... or of object-to-object connections, but will probably zigzag from one to the other (Latour, 2005, p. 75)" in their continuous association as a network (see also Law, 1992). Thus, Chug and Hancock (2009) offer some directions for joining ANT and organizational aesthetics.

We advocate that, ultimately, tracing senses and aesthetic knowledge networks will lead us to the material elements. For example, drawing on ANT, Blanchet (2018) investigates the process of constructing market categories by organizers and exhibitors at a trade fair. The author identified that visual inscriptions such as pictures, logos, and catalogues established an aesthetic, ethical, and fashionable image of the sector. The study reveals the role of visual in making the abstract concrete and shows that "market representations cannot be separated from their material media" (Blanchet, 2018, p. 393). This illustrates the idea that entanglement ${ }^{1}$ of material (e.g., pictures) and meanings (e.g., fashionable image) may enact phenomena, such as aesthetic/technical controversies, and constitute organizational reality over time (Scott \& Orlikowski, 2014).

As Barad (2007) points out, it is worth to note that "to be entangled is not simply to be intertwined with another, as in the joining of separate entities, but to lack an independent, selfcontained existence. Existence is not an individual affair. (Barad, 2007, p. 9)" Thus, a phenomenon exists as a consequence of the relations of heterogeneous elements. In this sense, our study highlights not the isolated capacity for an agency of the material, but the association between humans and non-humans (Latour, 2005).

Therefore, the idea of inscriptions is instructive at this point. The inscription can be apprehended as a descriptive concept to understand how organizations circumvent controversies through practices that seek to insert certain patterns or attributes into an artefact. Akrich (2000) points out that inscriptions "define the framework of actions together with the actors and the space in which they are supposed to act. (Akrich, 2000, p. 208)" To produce inscriptions means

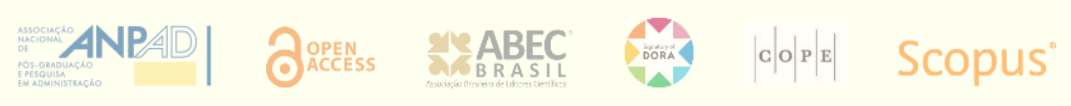


embodying certain patterns or attributes into a technical object so that the designers can anticipate the action of others who use that artefact. Interests are inscribed (Akrich \& Latour, 2000) in those heterogeneous elements.

Therefore, inscriptions produce scripts/scenarios capable of structuring organizational action (cf. Akrich, 2000). After all, inscribing is about ordering and not just the production of meaning (Cooper, 1989). The example offered by Akrich and Latour (2000) is exemplary, as it demonstrates how a large and heavy key ring reminds guests of it, so they do not forget it in aleatory places. The key ring conditions the action of the guests in some way. For the case in context, the gambiarra somehow structures what will be done and experienced by the actors assembling aesthetic experiences or even limiting behavioral options (Gagliardi, 2006). As inscriptions that structure scenarios/scripts become the subject of controversy, the notion of translation makes it possible to understand its dynamics (Akrich \& Latour, 2000). Controversies arising from accounting for a material element, such as float design, trigger the translation of varied and contradictory interests.

Translation can be understood as the process of transformation (Latour, 1987) by which something becomes equivalent to another (Law, 1999). It entails the combination of distinct interests (e.g., technical and aesthetic) as well as operations mobilizing a series of human and nonhuman elements (Latour, 1995). Translation carries meanings of both words and things: "things can be translated into words, and words can be translated into things" (Czarniawska, 2013, p. 365). Such procedures can be mapped through the analysis of the controversies that the object of translation engenders cartographically (Latour, 2005; Venturini, 2010a, 2010b).

\section{Cartography of controversies}

Cartography of controversies offers a means for researchers to study an actor-network while treating human and non-human elements in a symmetrical way (Law, 1994). The controversy is the disagreement between multiple actors starting with the recognition that they cannot ignore each other (Venturini, 2010a). In organizational studies, controversies concern disagreements about the way an organizational activity is managed (Hussenot, 2014). In general, disagreement occurs when a situation (e.g., production of floats) or an artefact (e.g., the float) that was taken for granted turns out to be questioned, becoming the subject of discussions among actors (Venturini, 2010a). Venturini (2010b) emphasizes that from birth to the closure of controversy it is essential to describe the interests of the divergent points of view enunciated, whether these differences are enacted by people or artefacts.

From controversies, observers can follow actors (Latour, 2005) and trace the networks being composed by both people and artefacts (Venturini, 2010a). Specifically, where a controversy irrupts around an artefact, its outcome, if resolved, becomes legitimate and shared within the organization as a way of performing a given activity, providing temporary stability (Lanzara \& Patriotta, 2001). Controversies around artefacts that are resolved lead to a new relation between actors. For example, Lanzara and Patriotta (2001) show how the day-to-day practice of a court of law was changed by the introduction of videocassette recording technology. The negotiation 
process became apparent during the reconfiguration of the actor-network, causing heterogeneous elements to appear, to be modified, or to be excluded (Hussenot, 2014).

Organizational controversies are enacted through particular organizing relationships and means of organizing. Thus, an organizational aesthetic phenomenon can be described by analyzing the actor-network involved in the course of (re)negotiation of old ties and the emergence of new ones (Venturini, 2010a). In doing cartography of controversies, one needs to follow, observe, and describe organizing relationships, organizational actors/actions, and (re)negotiation practices, allowing material elements to be included in analyses of organizational aesthetics. Instead of focusing on isolating elements (e.g., beauty or artefacts) and analyzing them separately as if they have inherent boundaries and were made up of pre-existing categories, we assume the entanglement of their constitution (Scott \& Orlikowski, 2014).

Accordingly, inscription and translation are two central notions for following controversies to analyze organizational (social, cultural, aesthetic, and material) issues (cf. Latour, 1987).

\section{METHODOLOGY}

The study is a inductive qualitative research (Berends \& Deken, 2019). Controversies analysis was used to identify the disagreements that arose during the floats' designing process, considering all possible actors (humans and non-humans) involved in questioning any subject (Venturini, 2010a). It was linked up with the actor-network theory to describe organizing symmetrically (Law, 1994). We focus on floats designing because they are the main aesthetic and visual representation of a samba school and show its majesty during the parade (Rosa, 2013). We gave special attention to temporary breakdowns (Sandberg \& Tsoukas, 2011) both during the floats production and the parade day. Temporary breakdowns mean the interruption or disturbance of activity, making actors start to concern themselves about what they do and bringing into view the sociomaterial practices (Sandberg \& Tsoukas, 2011). This helped us understand the relation between the aesthetic dimension of floats production and their technical/material issues.

Following the actors, as suggested by ANT (Latour, 2005), led us to trace the network of carnival projects beyond the samba school members and the floats that were the elements most immediately involved in the focus of the research. This included investigating broader aspects such as the carnival festival and more specific aspects such as the very samba school organization and the jury. According to ANT, they are all elements that should be analyzed in the same terms and not as separate dimensions.

\section{Data collection}

This research was conducted by the first-named author in a samba school of the special group of the city of São Paulo. The fieldwork began in mid-September 2009 and ended in February 2010. Data collection occurred through non-participant observation, semi-structured interviews, and documents. The focus of the fieldwork was the harmonia sector, which is responsible for the

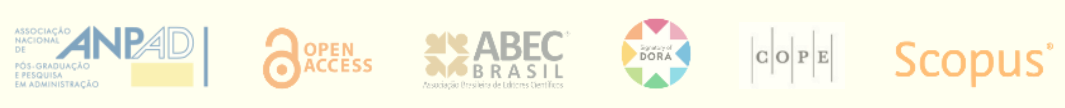


management of the school shed where the activities that involve the production of floats take place. The production of floats is part of the samba school's carnival project. The researcher had two main informants that are called Informant A and Informant B for preserving their identities.

During six months of observations, notes were made in a field notebook that was expanded in a text editor. In this period, the researcher participated in harmonia sector's meetings, rehearsals on the school court, and visits to the shed. Besides, technical rehearsals at the sambadrome and the removal of the floats from the shed in the week before the samba school parade were observed.

At the end of the fieldwork, the researcher paraded as a samba school member. By following the actors and their associations (Latour, 2005), we were able to traverse different spaces and identify a wide variety of human and non-human actors involved in the controversy under analysis.

In addition to the observations, semi-structured interviews were conducted with 19 members of the harmonia sector. They had an average duration of 48 minutes. The interviews allowed us to better understand the different points of view of the actors regarding the controversies (Venturini, 2010a). Documents related to the production of the parade were collected, such as the judges' evaluations and internal school documents. Photographic records were also made.

The researcher was not allowed to photograph inside the shed nor during the parade. To circumvent this limitation, a survey of photographs and videos about the parade was made, which were released by the press or made available on the YouTube platform.

\section{Data analysis}

The data were analyzed by the technique of codification and categorization (Bryant, 2017; Corbin \& Strauss, 1990; Glaser \& Strauss, 2006). As the data were collected, it was digitized and analyzed, since data collection and analysis are interrelated processes (Corbin \& Strauss, 1990).

Chronologically, field notes, documents, photographs, and interviews were ordered so that we could identify the controversies during the whole process of floats productions and trace the network of actors related to them.

The first step was to read and reread all the material so that we could become entirely familiar with the collected content. During the reading and revision of the material, we made annotations in the texts and indications in the documents about the controversies presented during the research. Later, we used open coding, in which we made constant comparisons (Glaser \& Strauss, 2006) between events/actions/interactions/arguments to find similarities and differences in the controversies surrounding the production of the floats. Doing this allowed us to identify two types of controversies related to the production process: aesthetic and technical. The aesthetic controversy is related to disagreements about the elements that can be captured by the human senses, such as the size, decoration, and beauty of the float. The technical controversy concerns disagreements regarding elements that make floats work properly, such as gear, electrical part, and quality of the structure. The constant comparisons helped us understand that controversies 
are not purely aesthetic or technical. Aesthetic controversies can bring to life technical issues and vice versa.

In the next phase, we used axial coding (Corbin \& Strauss, 1990) to establish relationships between these two controversies, determining the conditions and the context in which they emerged, the actors' responses and reactions to those disagreements, as well as the consequences of actions and interactions (Bryant, 2017). We identify that the controversies emerged in a context of time and resource constraints, generating consequences on the samba school's parade day, and being solved by gambiarras. Gambiarra is a creative problem solving widely used by actors through their sensible knowledge of what actions might work to settle the controversies between aesthetic and technical dimensions of floats' production (see Figure 1 for the analysis process).

The name of the samba school and its members have been omitted or changed to preserve their identities.

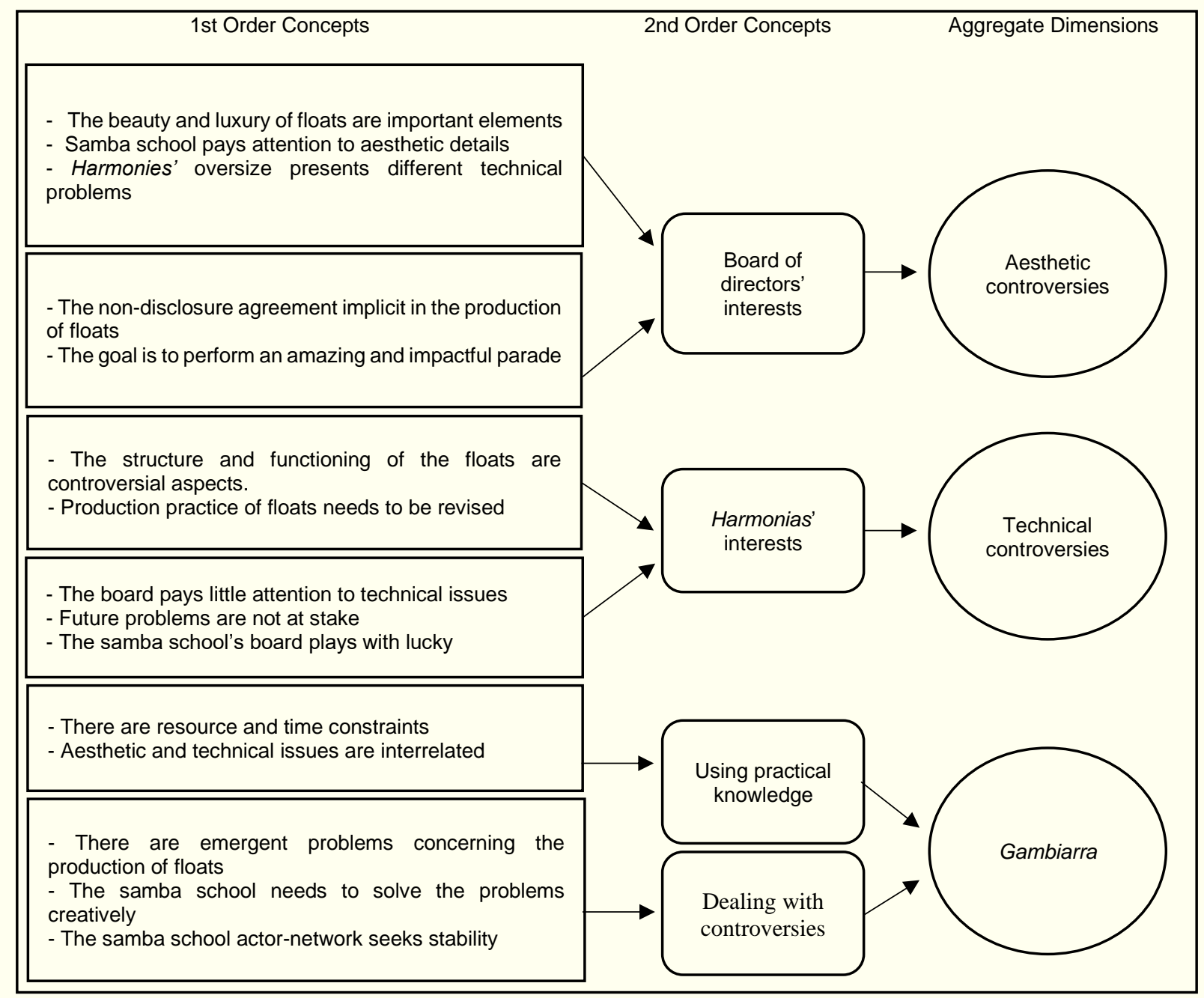

Figure 1. Strategy for coding the data

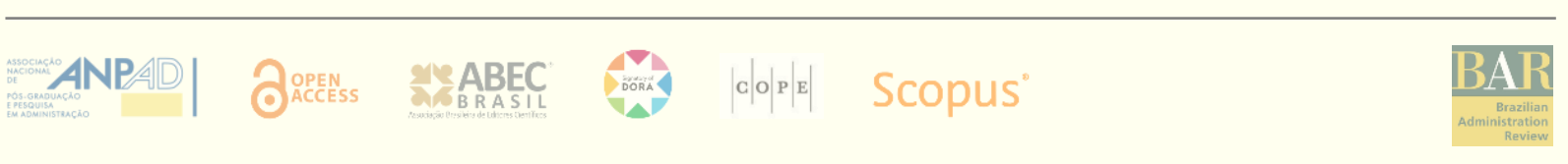




\section{RESULTS}

\section{Producing the aesthetics of floats}

Floats are the most visible elements in a carnival parade due to their aesthetic foundations (colors, lights, size, shape, movement). In the floats, parade the prominent people of samba schools (many of them artists or sportsmen) who wear large and luxurious costumes. The float is the combination of people with material elements that shape the aesthetic dimension of the parade, making the carnival show enjoyable for audience and presenters. The floats are kept in secret until the last day before the parade. This strategy seeks to create a sense of surprise for the audience. They are transported to the avenue covered by black tarpaulins so that no one can see them (Figure 2).

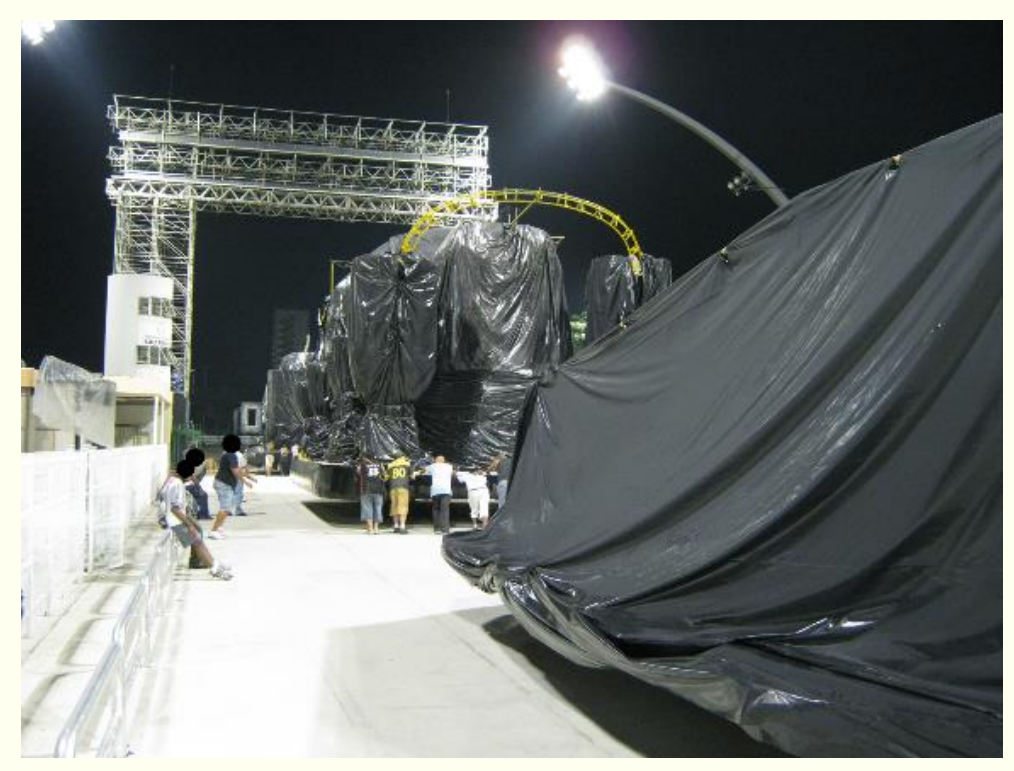

Figure 2. Floats being taken to the competition waiting $\operatorname{area}^{2}$.

Note. Photographed by the first-named author.

As the jury's rigor with the aesthetic details of the parades has increased over the years, school members have developed a sensitivity to this dimension in the production of the carnival show. Building floats requires a lot of work and careful attention to detail that can make a difference on the avenue since samba schools are subject to strict judging criteria. The following field note shows the issue of confidentiality being addressed between Informant B and the shed coordinator.

"Informant B and the coordinator talk about the fact that the carnival commission wants to restrict people from accessing the samba school shed ... because the samba school can't risk important information coming out of it. The coordinator then gave the example of a part of one of the floats that has a kind of pendulum that, according to him, is something innovative and that no one has ever done before in the history of carnival. He said it would be bad if someone 
talked about this innovation to others because it would lose its surprise effect on the audience on parade day (Field Notes - 14/11/09)."

Often during the process of assembling the float structures, there is a need to make gambiarras due to time and resource constraints or because time and resources end up being directed to the elaboration of sculptures, props, and/or finishing of floats. Without gambiarra is impossible to keep activity or project going, as shown below.

\footnotetext{
"While we were eating and talking at a gas station near the shed, Informant B said that the motorcycle crowns were not bought. These engine parts would be used to move a float that has been constructed around the figure of Nelson Mandela. He said the board members did not want to spend money on it. Then they asked the shed staff to make a gambiarra with something that would replace the motorcycle crowns (Field Notes - 01/16/10)."
}

The aesthetic and technical dimensions of carnival production are inseparable. The aesthetic 'facet' is composed of material elements that support and enact it. This association of heterogeneous elements has direct implications for samba schools' performance on the avenue, as we will see later when we address the day of the parade. But first, it is worth mentioning that the float construction practice generates controversies, especially concerning the size/shape (aesthetic dimension) and the mechanical/structural issues (technical dimension) of the floats.

\section{Aesthetic vs. technical controversy}

Some controversies may seem more of an aesthetic issue while others more of a technical one. However, they are entangled and enact two sides of the same coin: while one is visible the other may be hidden, but the whole picture is only produced through relations. A particular aesthetic controversy (e.g., size of the float) revealed several technical issues (e.g., old structures that do not support much weight). A technical controversy related to project management (e.g., budget and deadline) brought to life an aesthetic issue (e.g., the absence of sculptures in one of the floats). Often, these controversies can only be resolved with the use of gambiarras.

The aesthetic and technical controversies emerge from the samba school board of directors' and harmonias $^{\prime 3}$ interests, respectively. These interests are complementary and conflicting. Complementary because without the basic structure it would be impossible to produce the aesthetic part of the float. Without the float's final artwork it would just be a jumble of irons and wood devoid of any plastic value on the avenue. Conflicting because the board's interest in the float's aesthetics reduces efforts and resources directed at its mechanical structure. This creates the feeling that the board members are 'playing with luck' and putting the samba school at risk by not worrying too much about the technical issues. In one of the visits to the shed, it was possible to observe an exemplary situation.

"Some samba school members are discussing that one of the floats has a sculpture that weighs three tons. Informant A is concerned about that. She says she is going to write a letter to board members warning that the float may not hold. Then, if there are problems, no one could charge

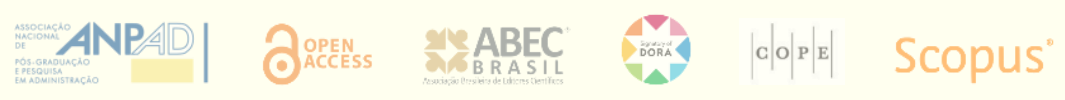


her with being weak on parade security, since board members are warned about it ... For her, the samba school boards are playing a lot with luck (Field Notes - 16/01/10)."

Unlike the artistic aspects (samba-plot, choreography, and sculptures), the technical part of the production of floats does not have specialists who acquired formal mechanical and electrical training and knowledge. Informant B suggested that "it would be interesting to have an engineer in the shed because some things are done without specific knowledge" (Field Notes). In some situations, a possible way out found by the harmonias to solve the controversies with the school board and get their job done was to use gambiarras: "in my team, if you need to overcome problems to go to the parade, we know how to do a gambiarra" (Informant B - Interview). The gambiarra appears as an unconventional solution to face situations that demand an immediate response to problems. The following dialogue shows how a seemingly technical controversy regarding the structure of the floats raised aesthetic issues about their size and beauty.

"Researcher: Are the float's structures old?

Informant A: They are very old. We use solder and hammers, as well as iron and wood pieces to fix it constantly. That is, we take a piece of iron that is somewhere out there and say: "Oh, let's solder it here," do you understand?

Researcher: But why not to build a new structure?

Informant A: That is the question that will not go away. It demands investment. You have to take all the floats apart. They [carnival board] would have to talk with some people of our [harmonia] group. They would have to talk with Mauro, and Mauro would see the bearing and the seam in question, for example, do you understand? He would see what needs to be done. You need to remove some iron, there is too much. The gears do not work at one hundred percent. The tires are of different calibers. It is cheaper to use iron on iron. Add this, add that [doing a gambiarra]. What happens at the end of the process? The [float] structure is already too heavy. There is no need to produce big cars. If you look at the latest parades all the cars are already beautiful."

As noted in the dialogue, the gambiarra may not look elegant from a first impression. Unlike the basic structure, we could say that the aesthetic aspect of a float does not accept gambiarras for it is evaluated in detail by the jurors: "the jurors are not there to evaluate who is the best, but who misses the least. The jurors are there to find errors, details of the aesthetic presentation on the avenue" (Carnival Director - Field Notes). In this sense, at least in principle, there is no room for using gambiarra solution in the aesthetic dimension for it can compromise the beauty of the float and the scores given to the samba school by the jurors. However, in some situations, the gambiarra is imposed by resource and time constraints.

So, it is also employed in the aesthetic dimension. This occurred with the last floats to be produced since the biggest investment is made in the abre-alas float. The abre-alas float has the role of opening the parade and creating a positive visual impression of the school on the avenue. It is the largest and the most imposing of the floats. It receives more investments and special attention from the school board. The following interview shows that a seemingly aesthetic controversy related to the last float's design and the use of sculptures to decorate it brought to life a series of technical issues related to project management such as budget, deadline, and risks. 


\begin{abstract}
"The only float that went to the avenue as thought and designed is the abre-alas. The rest, actually, like, goes as the money comes in ... The fifth float, for example, was supposed to come with twenty-two sculptures, which were the football World Cup Keepers. Have the sculptures arrived? Where are they? They were all behind [the shed] where the parked floats were. Why was everything thrown there? There was no financial support and not enough time to finish the float. What was done [on the day of the parade]? They picked the old school members up, topped them up in the float. But it was not their place there" (Informant B - Interview).
\end{abstract}

The mentioned examples illustrate the inseparability of technical and aesthetic controversies and the frequent use of gambiarra for solving the problems. Although there is initial planning for floats' designs, they are shaped as they are developed through the available material for their construction. The carnival project can rarely be accomplished as defined initially by the samba school. Throughout the process of producing the parade, the aesthetic and technical elements of the floats undergo various transformations, many of them using gambiarras. Even with an intense rehearsal routine for several months before the official presentation on the avenue, problems also happened on the Carnival Day parade itself.

"As much as we rehearse, like on-court and technical rehearsals, the parade itself has no rehearsal, it is a show that has to happen on the day that was scheduled, at that specific time, and many things become clear at that time only. So, this planning is very difficult [...] It is impossible to rehearse with the floats. So many things, no matter how thorough the planning is, only happen on Carnival Day" (Carnival Director - Interview).

When organizing the production of the parade, what was planned may change and become disorganized. This disorganization is the cause of many controversies. Once controversies are established, school members seek to resolve them employing gambiarras. There is a constant movement of organizing and disorganizing due to the various technical and aesthetic elements involved in the production of floats, but mainly because of the entanglement of these two dimensions. The same can be seen on the day of the parade. The aesthetic and technical issues may conflict, demanding live changes to be made, as shown below.

\title{
Putting floats into action
}

Harmonias make a great effort to ensure that floats do not become disorganized during their production. However, the focus on their aesthetic rather than mechanical dimension created technical difficulties and generated practical implications that were reflected on parade day. One of these problems was the driver's visibility of the floats, which was practically nil. The float's driver stands under it using a steering wheel created through a gambiarra. No one sees the driver nor the results of the gambiarras made to the wheel of the float. Therefore, the 'ugly' aspect of carnival production is hidden. Without having a complete view, drivers cannot calculate how much to turn. Hence, the float may move at a greater angle than the couplings between the parts can support. According to Informant B, this is what happened when samba school members were trying to position the abre-alas float on the competition waiting area on the day of the parade.

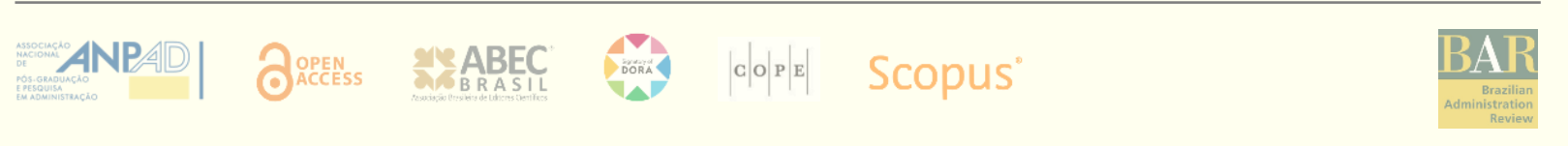


This float had serious problems entering the avenue:

"It is critical that the driver has an adequate range of vision, but often the driver has not an adequate range of vision. That is what I have explained to you now. They warned the driver to go to the right. The driver went right. So what? How much to the right? The driver is turning, right? Then the car took that extra-unwanted sprain" (Informant B - Interview).

The 'sprain' that the interviewee refers to means the pressure exerted by the hitch articulation of one part of the car on the other, holding the power cable that ran through the float. The same interviewee also states that "they [the people responsible for the electrical part] are passing [the cables] wherever they go, they do not care about anything. Long story short, the wire of the electric generator got sandwiched." Controversies around the aesthetic and technical dimensions as well as gambiarras developed throughout the production of floats were reflected on the avenue. These problems did not prevent the abre-alas float from entering the avenue and performing its part during the parade. In this case, the gambiarras fulfilled well their role of putting the car on the avenue and making its parade. Yet, the same did not happen with the last float.

This float had an old problem with its driving due to constant gambiarras made to its structure. At the moment of putting it on the avenue on the day of the parade, the steering braked, making it difficult to move. The float was very heavy because, in addition to the weight of its own structure, there were still several people on it. These people were the old school members who were put in place of the sculptures that were not produced for lack of resources, as mentioned in the previous topic. The competition waiting area has a slope designed to drain rainwater. As subtle as it may be, it makes a significant difference when pushing a float with a few tons in the opposite direction from the slope. In the words of the Singing and Evolution Coordinator:

"The last float had less merendeiros ${ }^{4}$ than necessary. It was time for the last float, with all the old
school members [on top of it] besides the weight of the float itself. The float would not move.
The float moved with difficulty, got on the ramp, and stopped. They had to figure out how to
get it out of there with a reduced amount of merendeiros. This was the last float, there was no one
else in the rear. The samba school drove away. By the time they got the float down the avenue,
the school was almost 250 meters away from it. This creates a hole between the samba school
and the last float. It is a hole that goes to Guinness Book. No samba school ever had a hole that
size on the avenue."

The solution was to remove some of the old school members from the top of the float and put them to parade on the floor. Then the harmonias brought together other members of the school who were still in the competition waiting area to help bolster the float. The hole mentioned by the interviewee (Figure 3) damaged the parade's aesthetic organization. As a result, the jury penalized the samba school as can be seen in the following judgments: "Wing 30 (board, council, songwriters) made a hole at 07:38 a.m. Due to these technical failures the school lost 0.25 points" (Juror 1); "A large hole was made in wing 30, leaving its components far apart in an attempt to overcome the left space" (Juror 2).

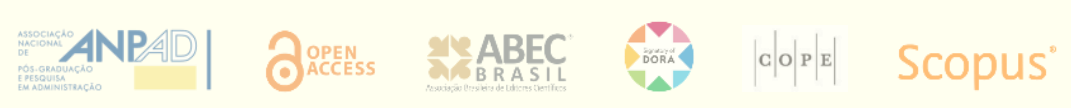




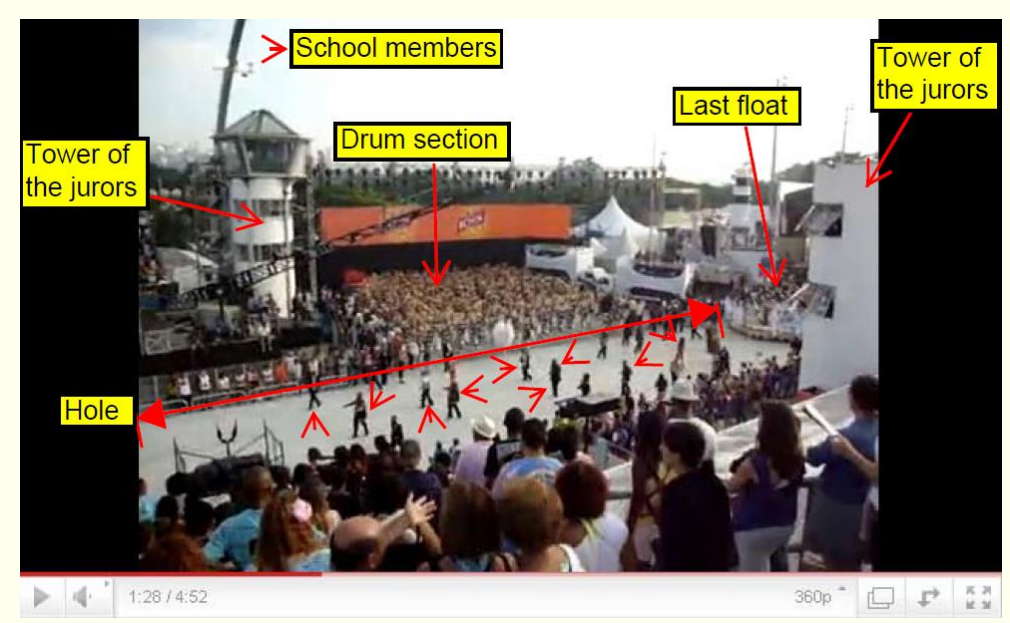

Figure 3. The hole between wing 30 and the last float.

Note. Coelho (2010).

While some gambiarras could resolve controversies without harming the school, others affected the samba school's performance in the competition. Nevertheless, the school was still among the top three in the ranking at the ending of the competition. Some samba school's members blamed the harmonia section. From this point of view, the problem would have been technical. On the other hand, some harmonias claimed that the carnival board failed. For them, the board was overly concerned with the aesthetic aspect and gave insufficient attention to the mechanical part of the floats and their production. The case in context shows that technical and aesthetic dimensions are entangled. Analyzing them separately limits the understanding of the aesthetics of organizational life.

\section{DISCUSSION}

\section{Controversies and the sociomaterial dimension of organizational aesthetics}

Beauty, form, and colors embedded in floats are the visible aspects of a samba school parade. Yet, technical aspects related to the daily efforts of harmonias also make itself present even being hidden by the beauty of the parade. Thus, looking for and understanding, the flow of inscriptions (e.g., gambiarras) allows access to the relationship between aesthetic and technical dimensions of organizing. Increasingly, organizational aesthetics can be understood as a series of material arrangements made up of artefacts (Strati, 2008a). Artefacts have an active role in controversies, circumscribing them, and enacting a shared meaning (Hussenot, 2014). The floats contributed to defining the controversial relationship between the harmonias and the samba school board.

Since the beginning, floats' size and weight was a controversial issue in organizing aesthetics. This aesthetic dimension brought to life controversies in which technical issues were debated and actors (harmonias and board) could not ignore each other anymore (Venturini, 2010a). Thus, a continuous translation process (Latour \& Woolgar, 1986) around the production of floats started, putting at the center of the discussion a hidden aesthetic aspect: the technical/material. 
Strati (2016) claims that the relationships between heterogeneous actors (human and material) give rise to the aesthetic side of organizations. However, as we have shown, this can only occur due to the association between human and non-human actors (Latour, 2005). However, this relationship is not always stable and may reveal controversies about the components of aesthetics (Guillén, 1997). The disagreements were an opportunity to observe how actors position themselves about the issue at stake (Latour, 1987) and act based on their knowledge to deal with emergent problems. The conflict situation demanded a solution. Therefore, the practice of making gambiarras took action.

The production of floats brings together various actors that translate their interests - technical or aesthetic - to generate a negotiation space in which to learn from project development is possible (Aubry, 2011). In this sense, aesthetic knowledge (Strati, 1996; Strati, 2016) was learned using gambiarra to fix failures in both the production practice and the day of the samba school parade. The controversies triggered harmonias' ingenuity to solve problems creatively, balancing aesthetic (beauty) and technical (material) dimensions of the carnival project. Hoorn and Whitty (2016) argue that there is a sensory experience associated with project managing and that "there are elements of project managing that are not explicit and cannot be understood in terms of a rules-base or pure cognition" (Hoorn \& Whitty, 2016, p. 71). Materiality is an integral part of aesthetic production even when it is unseen on the surface (Strati, 2008a). Thus, gambiarra can be understood as an inscription in the sense that it acts and shifts the actions of others (Akrich \& Latour, 2000). It becomes a pathway for action, structuring actors' sensory experience and behavior (Gagliardi, 2006).

Despite the recognition of materiality in organizational aesthetics (see Gagliardi, 2006; Stigliani \& Ravasi, 2018; Strati, 1996), the focus of studies usually falls on material artefact conceived as a closed and stabilized black box and not as an actor-network composed of heterogeneous elements (Law, 1992). Sage, Dainty, and Brookes (2011) highlight the relevance of considering the role of non-humans within a project, such as a samba school parade, to understand the complex relationship between heterogeneous actors, especially when aesthetics is an essential element of the creative work (Boxenbaum et al., 2018).

Non-humans create a negotiation space in which controversies are debated (Hussenot, 2014) and the translation of varied actors' interests (board and harmonias) occurs. Although the interests may seem contradictory, beauty cannot be produced without the hidden technical details. In fact, aesthetics and technique can be combined (Guillén, 1997). Austin, Hjorth, and Hessel (2018) show that "economic and aesthetic perspectives can 'live with' one another and be combined to actualize new ideas. (Austin, Hjorth, \& Hessel, 2018, p. 1515)" The authors indicate that conversation and collaboration help solve controversies between managers (who defend a technical perspective) and designers (who defend an aesthetic perspective). Although our case shows the entanglement of aesthetic and technical/material dimensions, different from these authors, we indicate that the coexistence of these dimensions is achieved by acting and putting gambiarra into practice. Our findings suggest that handling conflicts can be made by getting the job done, especially when there are time and resource constraints. 
The aesthetic dimension is not only made up of visible, tasteful, and evaluative aspects. It is an actor-network "in which bits and pieces from the social, the technical, the conceptual, and the textual are fitted together" (Law, 1992, 381). The components of organizational aesthetics should not be considered in isolation and apart from material bits and pieces for the relation between them create the whole picture (Hoorn \& Whitty, 2016) of what is being experienced by samba school's members, audience, and jurors. Therefore, gambiarra was an attempt to fit and link aesthetics and technique, beauty, and efficiency. There was the need to create beautiful floats and at the same time to use resources efficiently once they were scarce and time was clocking. This shows that the aesthetic dimension is a technical matter as well, that is, materiality is performed in practice and enacts aesthetics (Puyou \& Quattrone, 2018). The findings showed that enacting the aesthetic dimension in a constrained environment is a matter of putting gambiarra into practice.

\section{Fixing problems: the gambiarra solution}

Although the balance between beauty and efficiency is possible (Guillén, 1997), to accomplish it is difficult. Our findings show that gambiarra was the solution that put actors' creativity into action to enact the balance between the floats' design and operation dimensions. In management and organizational studies, a small number of investigations explore gambiarra as an improvised, flexible, and provisory solution (e.g., Amado \& Brasil, 1991; Islam, 2012). However, these studies do not establish a deep and clear definition of it. Based on our empirical results, we define gambiarra as the unconventional local use of technical knowledge capable of generating a creative solution from any available resource to solve a problem temporarily. Although this definition assumes gambiarra as a process, it may be considered a product as well. The creative solution itself that arises from the use of scarce resources to solve problems can be considered a gambiarra. Each aspect of the definition is explained below.

Gambiarra is unconventional because it usually does not follow the standards and rigors of technical knowledge. As we showed, Informant B complained about the absence of an engineer to accomplish some tasks that could not be suitably performed by anyone. In the absence of an expert, the practitioners use sensible and practical knowledge to solve problems in a creative way. Studying four R\&D project teams, Rosso (2014) found out that constraints (e.g., time and resources) stimulate team members to identify novel approaches and employ unusual ways to solve problems. As an unusual way of solving problems, gambiarra has little concern with aesthetic elements intrinsic to technical knowledge. It may also seem like a non-elegant and inferior solution from a first impression. However, gambiarra can be elegant and useful. It can be elegant in creating harmony between the parts of the floats with enough discretion so that the jurors do not identify possible problems. This is what happened with abre-alas float at the beginning of the parade. Therefore, it also proved to be useful so that the ultimate aesthetic goal of beauty and luxury of the floats could be presented on the avenue. Doing so requires a sensible knowledge (Strati, 2016), a way of knowing by acting (Strati, 2005a) applied in situations of time and resource constraints. Gambiarra connects the hidden world of technicalities and the visible world of beauty.

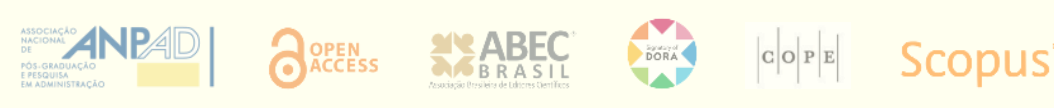


The local feature of gambiarra involves cultural, social, political, and economic dimensions linked to the context in which it is put into practice. This is related to the assimilation of new aesthetic aspects that make up the context of samba schools' parade. These elements have been well documented, such as the spectacularization of the carnival; the media as a commercial vehicle of the show; the entry of professional carnival artists in samba schools; the political criticism carried out by the parades; and the presence of judges with refined aesthetic standards (see Goldwasser, 1975; Queiroz, 1999; Rosa, 2013). The context influences how the aesthetic elements are manifested in specific situations. For example, to discuss the aesthetic dimensions of accounting, Puyou and Quattrone (2018) showed the different context aspects (historical, cultural, and social) in which legitimacy was created through visual and material artefacts. In the carnival case, these broader factors contributed to increase competition between the schools and lead them to be increasingly creative in their presentations.

Once gambiarra is employed to fix a problem, it generates a new way to do some task or a new use for some material not thought of before. Whereas creativity is the production of a novel and useful idea (Amabile \& Pratt, 2016), gambiarra can be considered a creative solution. For example, instead of putting the twenty-two unfinished sculptures on the fifth float - risking being penalized by jurors -, samba school workers replaced them with former members of the school who could dance during the parade and give elegance to the float. Therefore, gambiarra depended on the ingenious and imaginative practitioners' skills to use aesthetic (Gherardi, Nicolini, \& Strati, 2007) and intuitive judgment (Stigliani \& Ravasi, 2018) to change float's form without prejudice to the samba school score. Since carnival production is a project developed to compete on the carnival, gambiarra could be applied to project management. Focus on the lived experience of actors in performing concrete practice of project management (Hoorn \& Whitty, 2016) may be helpful to identify the knowledge and creative skills used by a project team to solve problems and take risk decisions in a situation where there are time constraints. Investigating the controversies emerged in two cases of organizational project management, Aubry (2011) highlights that the translation process performed by actors in dealing with disagreements was a learning opportunity for actors. Our case reveals gambiarra as an inscription that creates an opportunity for actors to learn and embody sensible knowledge through the interaction with other people and artefacts (Strati, 2007) increasing their ability to produce a creative solution.

The use of any available resource occurs because gambiarra usually arises in contexts where they are scarce. As mentioned by Informant A, the lack of money to invest in floats make any wood or iron pieces an asset to be used in the construction of floats. Julio and Tureta (2018) have discussed the reuse of materials in carnival production, showing this process as bricolage and creative endeavor. Samba school workers make the familiar strange (Shalley \& Zou, 2008), turning useless objects into a masterpiece artefact through the combination of different materials. Thus, gambiarra is a sociomaterial solution: it involves the entanglement of social and material (Scott \& Orlikowski, 2014). Artefacts play an important role here; they are sensed by touch, hearing, and sight, and through their ongoing interaction with humans they produce sensible knowledge (Strati, 2007). The project management example is illustrative again, once project managing is not a purely cognitive activity (Hoorn \& Whitty, 2016) and could embody some aesthetic and material dimensions. Taking seriously the role of materiality in organizational 
aesthetic and specifically in project management redirects researchers' attention to available objects used, for example, to create prototypes by gambiarra. Elsbasch and Stigliani (2018) pointed out that physical artefacts and prototyping can boost a culture of experimentation and risk taken in organizations, which is interesting for innovation projects, especially those that have resource constraints.

Despite its usefulness, gambiarra is a temporary solution. Although some practices can become legitimate if its outcome is successful (Lanzara \& Patriotta, 2001), gambiarra should be seen as an experimental and not a final approach because it tends to be risky from a functional and aesthetic point of view. In the long run, if the result of the gambiarra is not further improved it might just collapse. Thus, it is useful to identify the risks inherent in some gambiarras to document the individual and overall risk of the project and gather information so that the project team can provide appropriate responses (Project Management Institute [PMI], 2017) to controversial issues. As we have shown, the mechanical parts of the floats had a lot of old gambiarras and until that moment had not been improved. On the day of the parade, the float weight made the steering to break, so the float lost time before entering the avenue. Hence, the aesthetic ordering of the parade was damaged, and the samba school was penalized.

Gambiarras and a disorganizing process characterized the production of floats. These two features are usually associated with a negative connotation because of a so-called lack of professionalism and their ugly representation of the production process. Weggeman, Lammers, and Akkerman (2007) suggest that, if the aesthetic organizational processes are ugly, it is unlikely that the final product or service will be beautiful. Our findings go in the opposite direction, showing that an 'ugly' and disorganized process is part of creative production. Furthermore, gambiarra is relational. It occurs as the association of heterogeneous elements. In this sense, the backstage will never be a faithful representation of the live-action. The show (live-action) can be beautiful despite the lack of beauty in the creation process (backstage). Evidence of this is the fact that the school was ranked in the top three samba schools competing that year. In the long run, gambiarra poses a risk but in the short run, it can be an option to solve a problem creatively.

\section{CONCLUSION AND MANAGERIAL IMPLICATIONS}

This paper aimed to analyze the aesthetic and material/technical controversies surrounding the production of parade floats from a samba school. Controversies make actors notice each other (Venturini, 2010a), helping us understand how aesthetic and material/technical dimensions of the carnival project were balanced. The disagreements between actors are part of the organizing aesthetics and should be recognized as such since the aesthetic is linked to technical aspects and they can clash sometimes. We showed that gambiarra plays a central role in settling temporary stability for the actor-network of organizing aesthetics.

Our main theoretical contribution demonstrates gambiarra as a creative problem solving based on sensible knowledge (Strati, 2007) used to deal with controversies. Gambiarra is related to actors' daily practices. It is the hidden side of organizational aesthetics because it is generally seen as an ugly aspect of organizing although it may sometimes be elegant. The new research stream

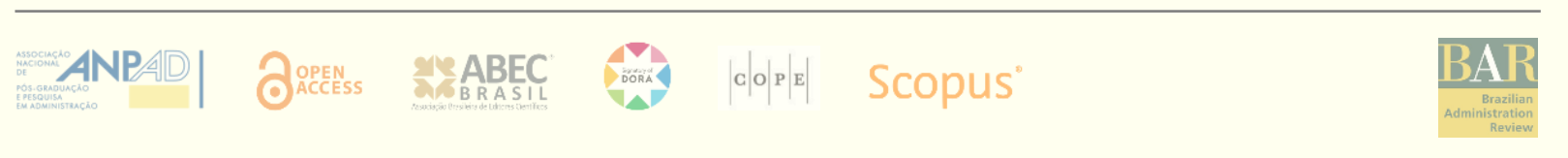


of project management that takes aesthetic dimension seriously (Hoorn \& Whitty, 2016) can benefit from these insights. As we showed, gambiarra has both a positive and a negative dimension for the development of a project. The positive side refers to contribution to the quick implementation of solutions and its potential in generating novel ideas. It gets the job done. The negative aspect suggests that gambiarra can become an end in itself, causing damage to project management. The case shows that gambiarra produced positive effects when it is the starting and not the ending point for creating solutions.

We also present controversy analysis as a useful tool to study aesthetics in organizations' settings. It proves to be an interesting method to identify the main disagreements involved in the relationship among heterogeneous actors (Hussenot, 2014) and to understand how the organizational aesthetics is the result of the translation of contradictory and complementary interests (Austin, et al., 2018). Controversy analysis helps researchers go beyond the cognitive approach to organizational aesthetics (Weggeman, et al., 2007) as it treats symmetrically human and non-human.

The managerial implications are threefold. First, managing projects in which aesthetics has central relevance to the results - such as in the creative economy - may put challenges for managers. They will have to balance technical and aesthetic dimensions: a design that achieves the best cost-benefit versus a design that is considered aesthetically superior (see Austin et al., 2018). Beyond the usual aspects of project management such as risk, cost, and deadlines (Müller et al., 2019), our findings indicate the relevance of aesthetics.

Therefore, the decision-makers, when managing the elements that govern aesthetic project management, should consider technical and sensible knowledge. Second, gambiarra may be an option to solve problems in ambiguity situation where there are time and resource constraints.

Specifically, it may be useful in innovation projects to generate creative solutions through prototyping and experimenting, allowing organizations to develop a culture of openness to ambiguity and risk-taking (Elsbasch \& Stigliani, 2018). Finally, although risk-taking is a desirable approach to creating new and innovative solutions, the potential for injury in project management can be minimized through calculated risk-taking. To balance both risk dimensions, we suggest that managers should start from established approaches such as PMI (2017) and follow its steps of project risk management. In doing so, they would benefit from being creative while not taking unnecessary risks that could harm the aesthetic project schedule.

Our findings offer some insights for future research. As we indicate, the production of a samba school parade is similar to the management of projects. Considering that the perspective of organizational aesthetics is underexplored in this literature (Hoorn \& Whitty, 2016), it would be interesting to understand how aesthetics influence the management of the technical elements of a project, given the possible controversies that may emerge between the two dimensions. Another avenue of research would be to investigate organizational contexts where the disorganizing process is an inherent part of management (e.g., serious economic crises, firestorms, and 
pandemic). This could shed some light on how gambiarra is used - for better or for worse - to deal with controversial issues demanding the creation of scenarios for uncertain times.

\section{Notes}

${ }^{1}$ Scott and Orlikowski (2014) borrow the notion of entanglement from the work of Barad (2007). According to Barad (2007), there is no such thing as a separate agency. Agencies do not precede their relations, they are "only distinct in relation to their mutual entanglement; they don't exist as individual elements" (Barad, 2007, p. 33). The assumptions of entanglement have also been developed by Sandberg and Tsoukas (2011) under the name of 'entwinement.' Based on Heidegger, the authors argue that "we are never separated but always already entwined with others and things in specific sociomaterial practice worlds... ...taking entwinement as the primary mode of existence means that for something to be, it needs to show up as something - namely, as part of a meaningful relational totality with other beings" (Sandberg and Tsoukas, 2011, p. 343). In addition to Heidegger's inspiration, the authors extensively ground the entwinement concept in the work of Wanda Orlikowski whose ideas we use in our discussion of entanglement. Both concepts (entanglement and entwinement) seem to be interchangeable and to describe the same phenomena. They assume the inseparability of any kind of entity in the researcher's analysis (for more details of the notion of entwinement see Sandberg \& Tsoukas, 2011, p. 343-344).

${ }^{2}$ Competition waiting area is a venue on the sambadrome where school members remain focused before the parade begins. In this space, the floats are placed, and the components of the wings are waiting for the right time to enter the avenue.

${ }^{3}$ Harmonias are the people who work in the harmonia sector.

${ }^{4}$ Merendeiros are the people responsible for pushing the floats on parade day. Merendeiros get cash to push, but they also get a snack before the parade begins. In Brazilian Portuguese, merenda means snack. The name merendeiro is a derivation of merenda.

\section{REFERENCES}

Akrich, M. (2000). The de-scription of technical objects. In W. E. Bijker; J. Law, Shaping technology/building society: Studies in sociotechnical change (p. 205-224). Cambridge: MIT Press.

Akrich, M., \& Latour, B. (2000). A summary of a convenient vocabulary for the semiotics of human and nonhuman assemblies. In. W. E. Bijker; J. Law, Shaping technology/building society: Studies in sociotechnical change (p. 225-258). Cambridge: MIT Press.

Amabile, T. M., \& Pratt, M. G. (2016). The dynamic componential model of creativity and innovation in organizations: Making progress, making meaning. Research in Organizational Behaviour, 36, 157-183. http://dx.doi.org/10.1016/j.riob.2016.10.001

Amado, G., \& Brasil, H. V. (1991). Organizational behaviors and cultural context: The Brazilian "Jeitinho". International Studies of Management $\mathcal{E}$ Organization, 21(3), 38-61. Retrieved from https://www.jstor.org/stable/40397183

Aubry, M. (2011). The social reality of organisational project management at the interface between networks and hierarchy. International Journal of Managing Projects in Business, 4(3), 436-457. https://doi.org/10.1108/17538371111144166

Austin, R., Hjorth, D., \& Hessel, S. (2018). How aesthetic economy become conversant in creative firms. Organization Studies, 39(11), 1501-1519. https://doi.org/10.1177/0170840617736940

Barad, K. (2007). Meeting the University Halfway: Quantum physics and the entanglement of matter and meaning. Durham, NC: Duke University Press.

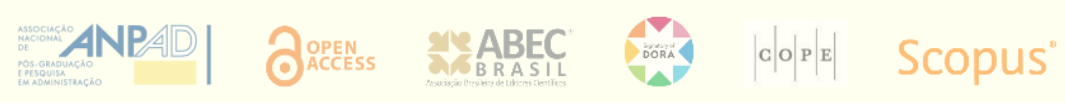


Berends, H., \& Deken, F. (2019). Composing qualitative process research. Strategic Organization, 1-13. https://doi.org/10.1177\%2F1476127018824838

Blanchet, V. (2018). Performing market categories through visual inscriptions: The case of ethical fashion. Organization, 25(3), 374-400. https://doi.org/10.1177/1350508417743805

Boxenbaum, E., Jones, C., Meyer, R. E., \& Svejenova, S. (2018). Towards an articulation of

the material and visual turn in organization studies. Organization Studies, 39(5-6), 597-616. https://doi.org/10.1177/0170840618772611

Bryant, A. (2017). Grounded theory and grounded theorizing: Pragmatism in research practice. New York: Oxford University Press.

Callon, M. (1986). Some elements of a sociology of translation: Domestication of the scallops and the fishermen of St. Brieuc Bay. In J. Law (Ed.), Power, action, and belief: A new sociology of knowledge? (pp. 196-223), London: Routledge \& Kegan Paul.

Callon, M. (1999). Actor-network theory - the market test. In J. Law, J., \& J. Hassard (Eds.). Actor network theory and after (pp. 181-195). Oxford: Blackwell.

Chugh, S., \& Hancock, P. (2009). Networks of aestheticization: the architecture, artefacts and embodiment of hairdressing salons. Work, employment and society, 23(3), 460-476. https://doi.org/10.1177/0950017009337060

Coelho, D. (2010, September 22). Bateria Vai-Vai - desfile SP 2010. [Vídeo file]. Video posted to https://www.youtube.com/watch? $=$ UN_jeNcqQuw

Cooper, R. (1989). Modernism, post modernism and organizational analysis: The contribution of Jacques Derrida. Organization studies, 10(4), 479-502. https://doi.org/10.1177/017084068901000402

Corbin. J., \& Strauss, A. (1990). Grounded theory research: Procedures, canons, and evaluative criteria. Qualitative Sociology, 13(1), 3-21. Retrieved from https://link.springer.com/article/10.1007/BF00988593

Czarniawska, B. (2006). Bruno Latour: Reassembling the social: An introduction to actor-network theory. Organization Studies, 27(10), 1553-1557. https://doi.org/10.1177/0170840606071164

Czarniawska, B. (2013). Things and words. Journal of Change Management, 13(3), 362-367. https://doi.org/10.1080/14697017.2013.822677

Duarte, U. C. (2013). A cultura carnavalesca em Porto Alegre: O espetáculo, a retórica e a organização da festa. Organizações Ė Sociedade, 20(64), 165-182. https://doi.org/10.1590/S1984-92302013000100011

Elsbasch, K., \& Stigliani, I. (2018). Design thinking and organizational culture: A review and framework for future research. Journal of Management, 44(6), 2274-2306. https://doi.org/10.1177/0149206317744252

Gagliardi, P. (1990). Artefacts as pathways and remains of organizational life. In P. Gagliardi (Ed.), Symbols and artefacts: Views of the corporate landscape (pp. 3-38). Berlin and New York: de Gruyter.

Gagliardi, P. (2006). Exploring the aesthetic side of organizational life. In Clegg, S., Hardy, C. \& Nord, W. (Eds), The Sage Handbook of Organizational Studies, (pp. 701-724), London: Sage.

Gagliardi, P. (2016). People die, things last: Surviving through artefacts. In R. Scruton (Ed.), Ephemera: Venice Fondazione Cini Summer 2016 (pp. 28-37). London: The Alpine Fellowship. Retrieved from https://www.pasqualegagliardi.it/sites/default/files/People\%20Die,\%20Things\%20Last.\%20Surviving\%20thr ough\%20Artifacts_0.pdf

Gherardi, S., Nicolini, D., \& Strati, A. (2007). The passion for knowing. Organization, 14(3), 315-329. https://doi.org/10.1177/1350508407076146

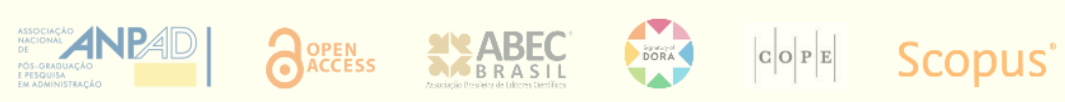


Glaser, B. G., \& Strauss, A. (2006). The discovery of grounded theory: Strategy for qualitative research. New Burnswick, London: Aldine.

Goldwasser, M. J. (1975). O palácio do samba: Estudo antropológico da escola de samba Estação Primeira de Mangueira. Rio de Janeiro: Zahar Editores.

Guillén, M. F. (1997). Scientific management's lost aesthetic: Architecture, organization, and the taylorized beauty of the mechanical. Administrative Science Quarterly, 42(4), 682-715. https://doi.org/10.2307/2393654

Hassard, J., Law, J., \& Lee, N. (1999). Preface. Organization. 6(3), 387-390. https://doi.org/10.1177/135050849963001

Hoorn, B. van der, \& Whitty, J. (2016). Let's discuss aesthetics for projects. Project Management Journal, 47(3), 6376. https://doi.org/10.1177/875697281604700306

Hussenot, A. (2014). Analyzing organization through disagreements: The concept of managerial controversy. Journal of Organizational Change Management, 27(3), 373-390. http://dx.doi.org/10.1108/JOCM-01-2012-0006

Islam, G. (2012). Between unity and diversity: Historical and cultural foundations of Brazilian management. European Journal International Management, 6(3), 265-282. https://doi.org/10.1504/EJIM.2012.047024

Julio, A. C., \& Tureta, C. (2018). "Turning garbage into luxury": the materiality in practices of the carnival production. Brazilian Business Review, 15(5), 427-443. https://doi.org/10.15728/bbr.2018.15.5.2

Lanzara, G. F., \& Patriotta, G. (2001). Technology and the courtroom: An inquiry into knowledge making in organization. Journal of Management Studies, 38(7), 943-971. https://doi.org/10.1111/1467-6486.00267

Latour, B. (1987). Science in action: How to follow scientists and engineers through society. Cambridge: Havard University Press.

Latour. B. (1995). A door must be either open or shut: A little philosophy of techniques: In A. Feenberg, \& A. Hannay (Eds), Technology and the politics of knowledge (pp. 272-281). Indiana University Press: Bloomington.

Latour, B. (2005). Reassembling the Social: An introduction to actor-network theory. New York: Oxford University Press.

Latour, B., \& Woolgar, S. (1986). Laboratory life: The construction of scientific facts. Princeton: Princeton University Press.

Law, J. (1992). Notes on the theory of the actor-network: Ordering, strategy and heterogeneity. Systems Practice, 5(4), 379-393. Retrieved from https://link.springer.com/article/10.1007/BF01059830

Law, J. (1994). Organizing modernity. Oxford: Blackwell.

Law, J. (1999). After ANT: complexity, naming and topology. In J. Law \& J. Hassard (Eds.). Actor network theory and after (pp. 1-14). Oxford: Blackwell.

Müller, R., Drouin, N., \& Sankaran, S. (2019). Modeling organizational project management. Project Management Journal, 50(4), 499-513. https://doi.org/10.1177/8756972819847876

PMI (Project Management Institute). (2017). A Guide to the Project Management Body of Knowledge (6th ed). Pennsylvania: Project Management Institute.

Queiroz, M. I. P. (1999). Carnaval brasileiro: O vivido e o mito. São Paulo: Brasiliense.

Puyou, F. R., \& Quattrone, P. (2018). The visual and material dimensions of legitimacy: Accounting and the search for socie-ties. Organization Studies, 39(5-6), 721-746. https://doi.org/10.1177/0170840618765013

Ratiu, D. E. (2017). The aesthetic account of everyday life in organizations: A report on recent developments in organizational research. The Journal of Arts Management, Law, and Society, 47(3), 178-191. https://doi.org/10.1080/10632921.2017.1303413

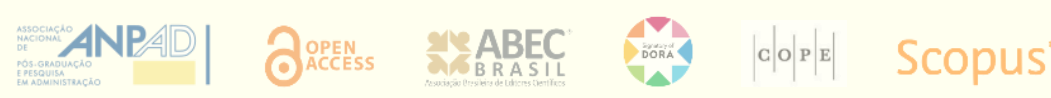


Rosa, P. U. (2013). O caráter composicional dos carros alegóricos das escolas de samba do Rio de Janeiro. Textos Escolhidos de Cultura e Arte Populares, 10(2), 151-168. https://www.epublicacoes.uerj.br/index.php/tecap/article/view/10222/8007

Rosso, B. D. (2014). Creativity and constraints: Exploring the role of constraints in the creative processes of research and development teams. Organization Studies, 35(4), 551-585. https://doi.org/10.1177/0170840613517600

Sage, D., Dainty, A., \& Brookes, N. (2011). How actor-network theories can help in understanding project complexities. International Journal of Managing Projects in Business, 4(2), $274-293$. https://doi.org/10.1108/17538371111120243

Sandberg, J., \& Tsoukas, H. (2011). Grasping the logic of practice: theorizing through practical. Academy of Management Review, 36(2), 338-360. https://doi.org/10.5465/amr.2009.0183

Siciliano, M. (2016). Disappearing into the object: Aesthetic subjectivities and organizational control in routine cultural work. Organization Studies, 37(5), 687-708. https://doi.org/10.1177/0170840615626464

Siggelkow, N. (2007). Persuasion with case studies. Academy of Management Journal, 50(1), $20-24$. https://doi.org/10.5465/amj.2007.24160882

Scott, S. V., \& Orlikowski, W. J. (2014). Entanglements in practice performing anonynity through social media. MIS Quarterly, 38(3), 873-893. https://dspace.mit.edu/handle/1721.1/91237

Shalley, C. E., \& Zhou, J. (2008). Organizational creativity research: A historical overview. In J. Zhou, \& C. E. Shalley (Eds.), Handbook of Organizational Creativity. New York: Taylor \& Francis Group.

Stephens, J. P., \& Boland, B. J. (2015). The aesthetic knowledge problem of problem-solving with design thinking. Journal of Management Inquiry, 24(3) 219-232. https://doi.org/10.1177/1056492614564677

Stigliani, I., \& Ravasi, D. (2018). The shaping of form: Exploring designers' use of aesthetic knowledge. Organization Studies, 39(5-6), 747-784. https://doi.org/10.1177/0170840618759813

Strati, A. (1996). Organizations viewed through the lens of aesthetics. Organization, 32(2), $209-218$. https://doi.org/10.1177/135050849632004

Strati, A. (2005a). Designing organizational life as 'aesth-hypertext': Insights to transform business practice. Organization, 12(6), 919-923. https://doi.org/10.1177/1350508405057476

Strati, A. (2005b). Organizational artifacts and the aesthetic approach. In A. Rafaeli \& M. Pratt (Eds.). Artifacts and Organizations (pp. 23-39). Mahwah: Lawrence Erlbaum Associates.

Strati, A. (2007). Sensible knowledge and practice-based learning. Management Learning, 38(1), 61-77. https://doi.org/10.1177/1350507607073023

Strati, A. (2008a). Aesthetics of organization. In S. Clegg, J. R. Bailey (Eds.), International Encyclopedia of Organization Studies (pp. 38-41), London: Sage.

Strati, A. (2008b). Aesthetics in the study of organizational life. In D. Barry \& H. Hansen (Eds.), The Sage Handbook of New Approaches in Management and Organization (pp. 229-38), London: Sage.

Strati, A. (2009). 'Do you do beautiful things?'. Aesthetics and art in qualitative methods of organization studies.' In D. Buchanan \& A. Bryman (Eds.). The Sage Handbook of Organizational Research Methods (pp. 230-45), London: Sage.

Strati, A. (2010a). Aesthetic understanding of work and organizational life: Approaches and research developments. Sociology Compass, 4(10), 880-893. https://doi.org/10.1111/j.1751-9020.2010.00323.x

Strati, A. (2010b). Ordinary beauty and aesthetic research in organization studies. In J. Przychodzen, F. E. Boucher \& S. David (Eds.), L'esthétique du beau ordinaire dans une perspective transdisciplinaire (pp. 79-93). Paris: l'Harmattan. 
Strati, A. (2016). Aesthetics and design: An epistemology of the unseen. In R. Mir, R. H. Willmott, M. Greenwood, M. (Eds.), The Routledge Companion to Philosophy in Organization Studies (pp. 251-259), London: Routledge.

Taylor, S. S. (2002). Overcoming aesthetic muteness: Researching organizational members' aesthetic experience. Human Relations, 55(7), 821-840. https://doi.org/10.1177/0018726702055007542

Taylor, S. S., \& Hansen, H. (2005). Finding form: Looking at the field of organizational aesthetics. Journal of Management Studies, 42(6), 1211-1231. https://doi.org/10.1111/j.1467-6486.2005.00539.x

Venturini, T. (2010a). Diving in magma: How to explore controversies with actor-network theory. Public Understanding of Science, 19(3), 258-273. https://doi.org/10.1177/0963662509102694

Venturini, T. (2010b). Building on faults: how to represent controversies with digital methods. Public Understanding of Science, 21(7), 796-812. https://doi.org/10.1177/0963662510387558

Weggeman, M., Lammers, I., \& Akkerman, H. (2007). Aesthetics from a design perspective. Journal of Organizational Change Management, 20(3), 346-358. https://doi.org/10.1108/09534810710740173

Weick, K. E. (2003). Organizational design and the Gehry experience. Journal of Management Inquiry, 12(1), 93-97. https://doi.org/10.1177/1056492602250523

\title{
Authors' contributions
}

$1^{\text {st }}$ author: conceptualization (lead), data curation (equal), formal analysis (equal), investigation (lead), methodology (equal), project administration (lead), supervision (lead), validation (lead), visualization (equal), writing-original draft (equal), writing-review \& editing (equal).

$2^{\text {nd }}$ author: conceptualization (supporting), data curation (equal), formal analysis (equal), investigation (supporting), methodology (equal), project administration (supporting), supervision (supporting), validation (supporting), visualization (equal), writing-original draft (equal) writing-review \& editing (equal).

\section{Authors}

\section{César Tureta*}

Universidade Federal do Espírito Santo

Av. Fernando Ferrari, no 514, Goiabeiras, 29075-910, Vitória, ES, Brazil

cesartureta.ufes@gmail.com

(DD https://orcid.org/0000-0003-0091-1114

\section{Bruno Luiz Américo}

\section{Instituto Federal de Santa Catarina}

Rua José Lino Kretzer, 608 - Praia Comprida - 88103-310, São Jose, SC, Brazil

brunolaa@hotmail.com

(iD) http://orcid.org/0000-0003-2615-6583

* Corresponding author

\begin{abstract}
Peer review is responsible for acknowledging an article's potential contribution to the frontiers of scholarly knowledge on business or public administration. The authors are the ultimate responsible for the consistency of the theoretical references, the accurate report of empirical data, the personal perspectives, and the use of copyrighted material. This content was evaluated using the double-blind peer review process. The disclosure of the reviewers' information on the first page is made only after concluding the evaluation process, and with the voluntary consent of the respective reviewers.
\end{abstract}

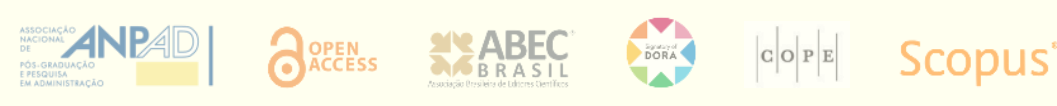

